\title{
PosFAUUSP 53
}

\section{BETWEEN BEERS AND HUBS: HERITAGE REHABILITATION IN LISBON}

\author{
ANA ELISIA COSTA \\ Universidade Federal do Rio Grande do Sul - Faculdade de Arquitetura \\ - R. Sarmento Leite, 320 - Centro Histórico, Porto Alegre - RS, 90050-170/ \\ (51) 3308-3116 \\ https://orcid.org/0000-0003-4829-5699 \\ ana_elisia_costa@hotmail.com
}

Received: 04/29/2021

Approved: 06/30/2021

\section{ABSTRACT}

A project, when signed by a star-architect, gains notoriety. Spectacularized, it transcends its own aesthetic gesture, communicating and validating cultural values and worldviews. Thus, it assumes an ethical dimension, which investigation is relevant for revealing ways of controlling culture and society. In the context of this reflection, the study adopts as an empirical object the mediatized project of the Browers Beato Brewing Company (2017), developed in Lisbon, under the seal of Eduardo Souto de Moura. The proposal is part of a larger project, the Hub Criativo Beato, which aims to rehabilitate a post-industrial complex and requalify the very east of Lisbon. Brewery, Hub and city, therefore, articulate themselves as inseparable parts of the same discourse that deserves attention. Analyzing the Brewery-Hub project, from an aesthetic-ethical perspective, is the objective of this study. Field and bibliographic research are the basis for the analysis of the context, the presentation of projects and the prospecting of possible impacts on the physical and social tissues involved. Universal and homogenizing, the solutions adopted allow to guide the need to deconstruct discourses and practices, in favor of a "fair" project.

Keywords: Heritage. Project. Browers Beato Brewing Company. Hub Criativo Beato. Lisbon

Pos FAUUSP, São Paulo, v. 28, n. 53, e185117, jul-dez 2021.

\section{RESUMO}

Um projeto, ao ser assinado por um star-architect, ganha notoriedade. Espetacularizado, ele transcende o seu próprio gesto estético, comunicando e validando valores culturais e visões de mundo. Assume, assim, uma dimensão ética, cuja investigação é relevante por revelar formas de controle da cultura e da sociedade. No contexto desta reflexão, o estudo adota como objeto empírico o projeto midiatizado da Cervejaria Browers Beato (2017), desenvolvido em Lisboa, sob a chancela de Eduardo Souto de Moura. A proposta se insere em um projeto maior, o Hub Criativo Beato, que visa reabilitar um complexo pós-industrial e requalificar a própria zona oriental de Lisboa. Cervejaria, Hub e cidade, portanto, articulam-se como partes indissociáveis de um mesmo discurso que merece atenção. Analisar o projeto CervejariaHub, em uma perspectiva estética-ética, é o objetivo desse estudo. Pesquisas de campo e bibliográfica embasam a análise do contexto, a apresentação dos projetos e a prospecção de possíveis impactos sobre os tecidos físicos e sociais envolvidos. Universais e homogeneizantes, as soluções adotadas permitem pautar a necessidade de desconstrução de discursos e práticas, em favor de um projeto "justo".

Palavras-chave: Patrimônio. Projeto. Cervejaria Browers Beato. Hub Criativo Beato. Lisboa

HTTP://DX.DOI.ORG/10.11606/ISSN.2317-2762.POSFAUUSP.2021.185117 


\section{INTRODUCTION}

In May 2018, several newspapers in Lisbon reported the event presenting the project of the Browers Beato Brewing Company, by the Super Bock group, by the architect Eduardo Souto de Moura ${ }^{1}$. In partnership with architect Nuno Graça Moura, the design occupies the former Power Plant of the Military Maintenance (MM) factory complex, in the parish of Beato, in Lisbon. This, in turn, was the target of a major rehabilitation project such as the Hub, Hub Criativo Beato (HCB). Skillfully publicized by the media, the event was one of many actions that sought to offer a positive view of the $\mathrm{HBC}$ project, as a strategy that was legitimized by inserting Lisbon into the global entrepreneurial context.

At the event, in line with the glamor of the culture of the spectacle (MONTANER, 2012; 2014), the "stararchitect" presented the design within the space to be projected, to an audience composed of representatives from the financial sectors and the political leadership, with representatives of the local community absent. Despite this absence, Rui Ferreira, representative of the Super Bock Group, mentioned the vague desire for involvement of the "resident beer community", possibly referring to the Lisbon Beer District ${ }^{2}$, which was consolidating in the region. In turn, Miguel Fontes, representative of the $\mathrm{HCB}$, probably indicated the actual target audience of the enterprise, by expressing the ambition to consolidate there a "meeting point for installed entrepreneurs” (MOREIRA, 2018).

From the event, speeches and the absence of the local community, discussions can emerge that transcend the very aesthetic gesture of the project being presented. Carried out as a "product for" and not a "process with" the community and aimed at the entrepreneurial public, could the HCB projects, including the Brewery, indicate the prevalence of its economic function, to the detriment of a possible social function?
By questioning the means and ends of these projects, ethical reflections are addressed. That is, values and worldviews that sustain them and that, directly and indirectly, control society's ways of being and acting (LARA, 2004). At the heart of these reflections, some of the dilemmas of contemporary Architecture and Urbanism are also centered. Thus, requiring from architects, traditionally "service providers" and linked to the aesthetic expression of the design, an expansion of awareness about the consequences of their actions or a clear ethical stance, as indicated by Montaner and Muxí (2014, p. 38):

If an architect wants to be recognized and appear in
the media at all costs, he/she will be condemned to
be loyal to the powerful and to adopt as a sham the
messages that the media and pressure groups tend to
promote. If he/she wants to be loyal to his/her social
function, he/she will be forced to go beyond his/her
professional, industrial and commercial coordinates
to be able to carry out an authentically cultured and
critical, multidisciplinary and collective work that
participates in social and cooperation projects.

In the context of this reflection, this study has as its theme rehabilitation projects ${ }^{3}$. As an empirical object, the $\mathrm{HCB}$ project is adopted for the former MM manufacturing complex and, as an inseparable part of it, the Brewery project for its former Power Plant. The aim of this study is to analyze such projects from an aesthetic-ethical perspective. It seeks to relate its spatial and programmatic propositions to the possible impacts on the social fabric involved. Therefore, in addition to visits to the riverside and industrial region of Beato and Marvila and to the MM complex, bibliographical reviews on heritage interventions and urban requalifications and on the study area are used $^{4}$. From these procedures, the work is structured

${ }^{1}$ Illustrate the argument: Melo and Castro (2018); Moreira (2018); Nunes (2018).

${ }^{2}$ Reference to three breweries - Dois Corvos, Lince and Musa - located in the parish of Marvila, neighboring the parish of Beato (BRANCO, RODRIGUES, 2019).

3 "Rehabilitation" is understood as a set of actions that focus essentially on the physical territory, through reconstruction, recovery and renovation works. It differs, therefore, from "regeneration", whose actions seek to integrate physical interventions with measures of social, economic and cultural cohesion (NEVADO, 2018).

${ }^{4}$ The work is part of a postdoctoral research (2019-2020), at the ISCTE-Lisbon, supervised by Paulo Tormenta. 
in three parts, in which the physical-social context of MM insertion is presented and analyzed, as well as the referred projects.

The analysis suggests the adoption of universal and homogenizing discourses and solutions that, for a long time, have focused on heritage, planning and design. From a perspective of overcoming the dilemma pointed out by Montaner and Muxí (2014), we seek to raise arguments that can feed discussions about the (re)meaning of our theories and practices, in favor of a "fair-project".

The understanding of "fair-project" starts from the recognition that any design action is, in itself, conflictual, potentially "damages" generating. By confronting and privileging interests between individual/collective, public/private or current/ subordinate powers, the action of the project includes/ excludes individuals around what should be shared, the "common" (RANCIÈRE, 2005). Thus, a possible "fair-project" would focus not only on the physical territory, but also on the social territory, developing reflections-actions sensitive to the desire for socioeconomic-cultural cohesion in the common sharing. In this context, the involvement of "all" affected in the project's conception-management stands out, refuting pre-judgments that some individuals are "incapable" of thinking-acting about the "common"; and the questioning of consensual judgments (aesthetic, cultural, legal) standardized by the current orders, because each case is, in itself, dissenting, thus requiring a specific and continuous examination. Therefore, "fair-project" is understood as one that seeks to amalgamate aesthetic-ethical dimensions in its work.

\section{CONTEXT}

In Lisbon, Grilo Street is close to the Tagus river, parallel to Infante D. Henrique Avenue. Its name is related to the former Quinta dos Grilos, refuge of nobles and stage of agricultural production, where, later, the Convento das Carmelitas Descalças, known as "grilas" and, later, the MM factory, which was dedicated to providing food to the Army, started to function. This former factory is now the object of the rehabilitation project as the HCB (Figure 1). It is, therefore, a territory made up of social overlaps - noble, religious, military and entrepreneurs - and programmatic - farm, convent, factory and creative hub - and programmatic - farm, convent, factory and creative hub -, transformations triggered by two great stages of decay in which the States, one liberal (1820) and the other neoliberal (current), intervened in the area.

\section{The first decay and a long stage of (apparent) prosperity}

The eastern part of Lisbon, historically, was an area of palaces for the holidays of the noble class, an area of agricultural production, with vegetable gardens, vineyards and olive groves, and an area with several religious convents. Affected by the great earthquake of 1755, convents and palaces were abandoned, characterizing the first stage of decay in the region.

With the liberal revolution (1820) and the extinction of the religious orders in Portugal (1834), the riverside part of this territory was "rehabilitated" with the occupation of the ruins by industrial activities that benefited from the proximity to the river, the port and the railroad (1856). In this context, the former Convento da Grilas was occupied by the MM Factory, in 1897 (JFB, n.d.)
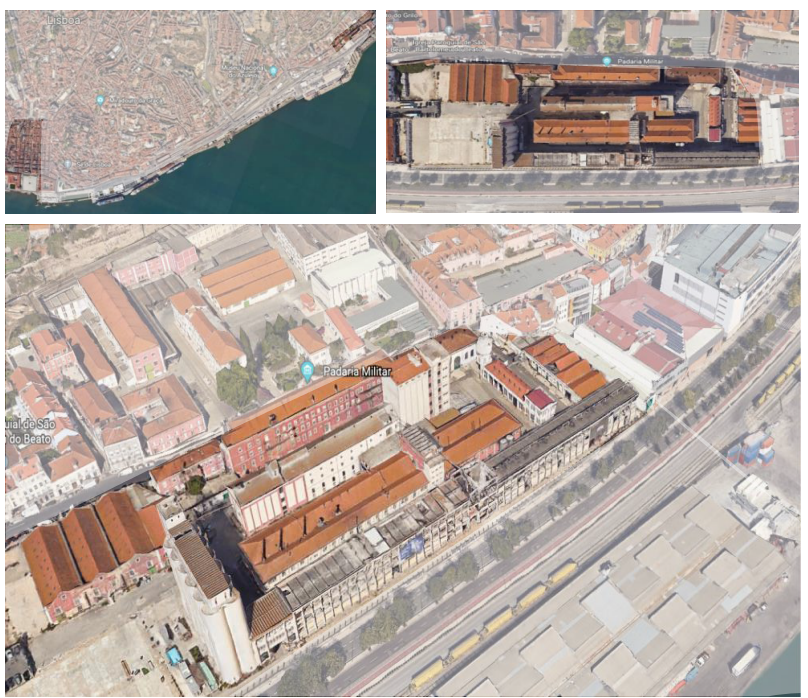

Figure 1: Location, top and aerial view. HCB. Lisbon. Source: Google Earth (base adaptation: by the author) 
Throughout the 20th century, this territory became an important industrial periphery of Lisbon. Factories, warehouses and workers' housing multiplied in Beato and Marvila. With different levels of precariousness, workers were accommodated in adapted buildings, workers' villages, "yards" and informal neighborhoods. Despite isolated experiences in the 1940s, such as the Madre Deus complex, it was only in the 1960s that the government invested in large scale in low-cost housing. In parallel, this working class organized itself into associative movements - assistance or linked to workers' struggles and culture -, which can reveal a local collaborative culture (JFB, n.d.; REIS AND SILVA, 2019).

In this physical and social context, MM was implemented involving numerous architectural and urban changes over time. Old buildings of Grilas were demolished and the factory expanded to the north, beyond Grilo Street, and to the south, over successive landfills on the Tagus. In the 1950s, with the construction of Infante D. Henrique Avenue, the boundaries of the complex were redefined.

In this expanded and cut territory, new buildings were built, followed by others that, in turn, underwent complex changes - adaptations, demolitions and replacements - that sought to include new programs and improve the factory's production line. Its complex and "mutant" program involved Grinding-RefectoryKitchen Factory, Power Plant, Bread-Dough-Cookie Factory, Sugar Refinery, Fried Factory, Coffee Roasting-Grinding, Flour Deposit, Confectionery, Canning Factory-Sawmill-Tinware, Meat Factory (sty, slaughterhouse, butcher and sausage). In addition to these uses, there were also installations and equipment, such as the trolley lines between buildings, the cereal vacuum between piers and silos (1923) and the overhead conveyor (1929) (HCB, 2018).

This process of change was especially emphasized during the 1940s, with the Second World War, and in the 1950s and 1960s, with the colonial war. With the end of the wars and especially with the 1974 revolution, the MM was reorganized and resized. After brief support to prominent groups in foreign countries in the 1990s, the factory was closed in 2011.

This process resulted in a complex with great extension, with $35.000 \mathrm{~m} 2$ and 20 buildings between Grilo Street and Infante D. Henrique Avenue. Three internal longitudinal streets organized and served internalized buildings and peripheral buildings, close to the sidewalk (on Grilo Street) or with a small frontal setback (on Infante D. Henrique Avenue). Which express different types and construction solutions and have different states of conservation and rehabilitation demands (Figure 2).

\section{The second decadence and new developments}

The deactivation of the MM was not only due to the obsolescence of its production, but was part of a long process linked to the global phenomenon of deindustrialization and repositioning of large industrial and port complexes, observed from the 1970s to the 1980s (OCHOA, 2015). Like the MM, warehouses, infrastructures and workers' villages in Marvila and Beato were gradually abandoned or underutilized from that period onwards. Thus, leading to a shortage of work and aggravation of social and urban problems.

From the end of the 1990s, however, there were initiatives to rehabilitate the Zone by the neoliberal state that, based on the economy and tourism, sought to insert Lisbon into the global map of large investments. In this context, initiatives such as the EXPO98 project and more recently the HCB project were promoted, legitimized by the need for economic dynamism in the region.

In parallel, especially from the 2010s onwards, "alternative" private initiatives are observed. Especially in Marvila and part of Beato, young people, who did not have access to real estate in downtown Lisbon due to the high costs, found in the old factory buildings places to work. There, they created a theme park dedicated to culture and leisure. There are nightclubs, 


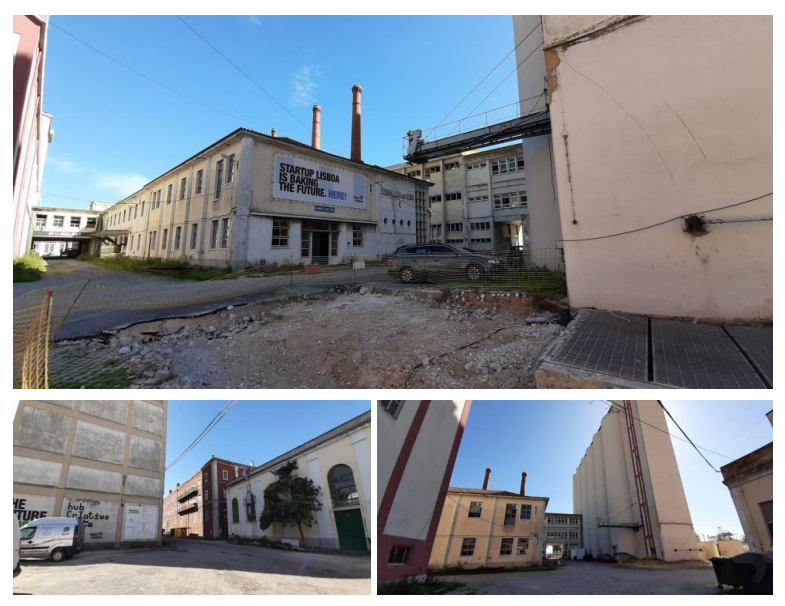

Figure 2: Views of the internal streets. HCB. Lisbon. Source: the author.

galleries, ateliers, coworkings, cafes, bars, restaurants, which explore a decadent aesthetic, to the taste of the hipster or cool public (COSTA, 2020) (Figure 3).

As well as post-industrial territories in other parts of the world, the Eastern Zone of Lisbon became the target of cultural agents, eager to intervene in "ruins" that reveal the deterioration of urban life. The zone has also attracted investors, eager for cheap real estate, low investments and quick returns; finally, it attracted the public power, a "benevolent" urban rehabilitator, attentive to the injection of international capital.

Exploring a nostalgic atmosphere and/or aestheticizing decadence, these interventions involve a slow erasure of existing-memory and an invention of consumable memories, which transforms the cultvalue of its heritage into an exhibition-value. Then, theatricalized, themed and touristic amusement parks appear. This touristic feature, by being disguised, weakens social and community networks that are unable to oppose ongoing projects, leading to the gradual process of gentrification ${ }^{5}$ (LIPOVETSKI; SERROY, 2015; KENDZIOR, 2014; MANTANER; MUXI, 2014). The 22@ project, in Barcelona, can illustrate the phenomenon, where the industrial memory of Poblenou was erased, under the discourse of recreating a "sustainable" industrial zone, linked to

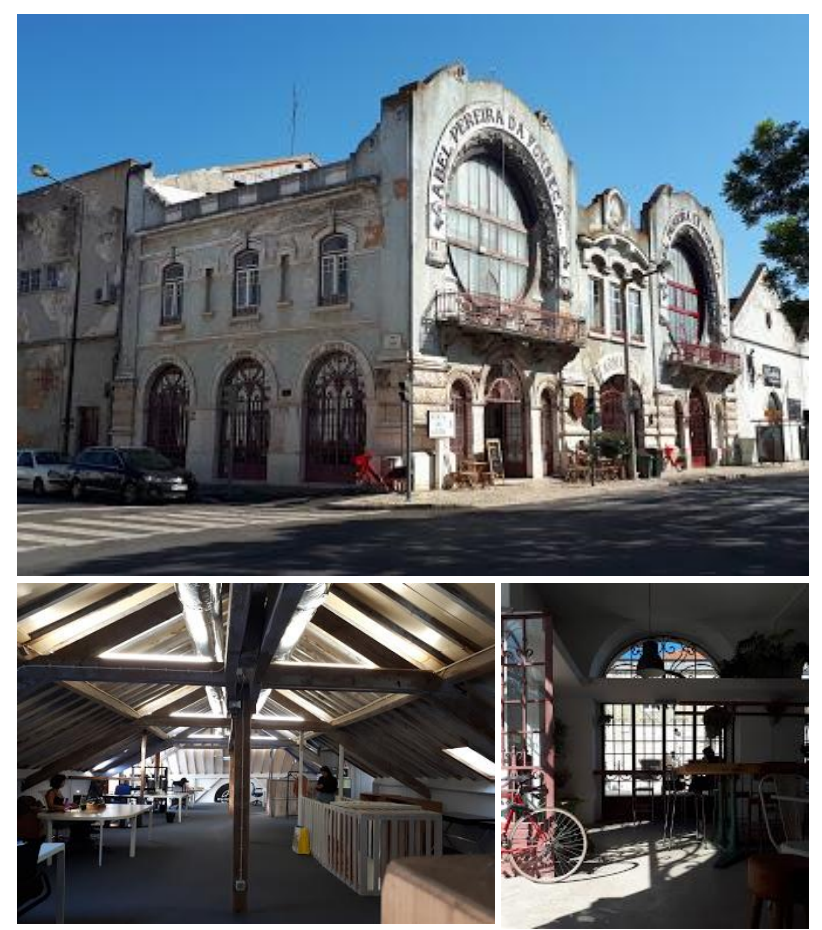

Figure 2: Views of the internal streets. HCB. Lisbon. Source: the author.

"technology and innovation" (MANTANER; MUXI, 2014), as proposed in Beato.

\section{BEATO'S CREATIVE HUB}

\section{About the project}

In 2016, the MM complex on the aforementioned stretch between Grilo Street and Infante D. Henrique Avenue, then owned by the Portuguese State, was transferred to the Municipality of Lisbon for a period of 50 years. The transfer included the rehabilitation of the complex to host the sixth edition of the Web Summit, the largest European conference in internet technology. Thus, boosting the consolidation of a cultural, technological and tourist pole, the HCB (HCB, 2018). The design of the project was delegated to the Startup Lisboa, a public-private company ${ }^{6}$ which, as an "intermediate actor", had autonomy to make decisions, even before the municipal planning department (LÖNNERVALL; SUNDELL, 2018).

${ }^{5}$ Social movements of resistance to the scenario should be mentioned, with Habita! (Inhabit!) and Stop Despejos! (Stop Evictions!)

${ }^{6}$ Non-profit association between the Municipality of Lisbon, Montepio Banco and the Portuguese Agency for Competitiveness and Innovation, created in 2011 (HCB, 2018). 
According to its memorial (HCB, 2018), the Hub aims to be "the largest center of entrepreneurship in Portugal and one of the largest in Europe". A pole of attraction and retention of talents and companies linked to three sectors - entrepreneurship, innovation-knowledge and creative industry -, which will contribute to positioning Lisbon "with the most innovative and contemporary at an international level". It also aims to be a mobilizing agent in the revitalization process of the eastern part of the city.

With an "access for all" discourse, permeability and accessibility strategies are outlined, exploring the $\mathrm{HCB}$ as a potential place for meeting, circulation, collective representation and for "consumption". In this perspective, the proposal is limited to "intentions" of physical interventions, understood as still deserving of further deepening - reducing the profile and opening new streets; opening and qualification for pedestrians; adoption of public transport and "sustainable mobility and of displacement; and public parking to meet the $\mathrm{HCB}$ and demands in the region.

In relation to the needs program, the complex will involve: Workspaces, focused on entrepreneurship, innovation and knowledge and the creative industry; Museum space, dedicated to the memory of MM; Commercial space, intended for sale, provision of services, food and necessary uses for the Hub; Housing spaces, with special residential spaces, such as co-living; Administrative spaces, technical areas and parking (Figure 4). Areas are also planned for global megacompanies, such as the Factory (entrepreneurship and innovation center, based in Berlin), the Benz-Daimler Digital Hub (from the Mercedes automaker), in addition to the aforementioned Web Summit, Startup Lisboa and the Super Group Bock, who took over the complex's cultural agenda (HCB, 2018).

\section{About criticism}

Considering the discourse, scale and audience of the HBC, it must be understood as part of a global urban competitiveness strategy, and its possible social

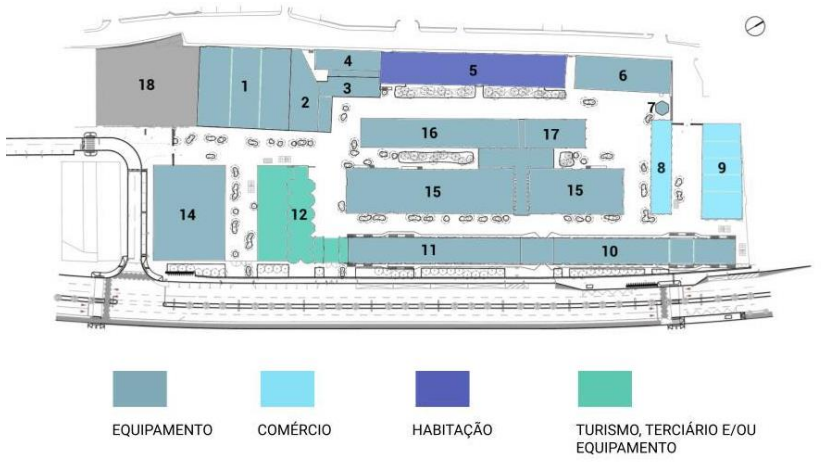

Figure 4: Proposed uses. HCB. Lisbon. Source: HCB (2021)

and economic impacts in Lisbon are not negligible. Despite an optimistic view of it, perceived as a cultural and economic success and as an exemplary case of "integration" of local-global and publicprivate communities (NEVADO, 2018; NEVADO; ANDRÉ, 2018), negative criticisms of the social and urban dimensions of the proposal began to emerge in the last three years (SCALZOTTO, 2020a; 2020b; LÖNNERVALL; SUNDELL，2018; GENNARI, 2018). Although still few in number, essentially, such criticisms denounce the $\mathrm{HBC}$ of neglecting social valuesin favor of exchange value, as in so many other projects guided by neoliberal economics. In this context, the Hub would be privileging the "talented" foreign public in its actions and its discourse of revitalizing the city would be used only to legitimize investments from specific sectors. As it is not very sensitive to the resolution of local problems, the proposal leads the authors to prospect the emergence of negative side effects.

Based on these criticisms and expanding them, two attributes highlighted in the project's memorial are re-examined here: "inclusive and integrative" (HCB, 2018). Thus, seeking to identify how they are expressed in the proposals for the use of public space and in the needs program presented here.

The opening of spaces to the public, according to the memorial, "in particular to the local community", is relevant, given the reduced number of public spaces in the region (LÖNNERVALL; SUNDELL, 
2018). However, in addition to physical access, it can be questioned whether the impoverished local population will have effective access to the services offered there, as they do not include the consumption capacity of various groups of the population, as noted by Gennari (2018). Moreover, the profiles of sought after entrepreneurs are little connected to the reality of local culture. On the other hand, the lack of solutions for the road-transport system does not seem to be responsible for the serious existing problems of connecting the eastern region of Lisbon with the rest of the city (OCHOA, 2005) and, with the forecast of a large influx of users, there are perspectives of worsening the situation ${ }^{7}$.

Regarding the program, despite mentioning the insertion of the "local economy", physical spaces or mechanisms for this purpose are not contemplated. Considering the profiles and vocations of the local community - needy, polarized between marginalized young people and the elderly, with an associative heritage and, today, linked to small businesses, services and few manufacturing activities -, opportunities for social activation or offers of training and economic activities aimed at this audience are not pointed out. A condition that is fundamental to ascend socially and economically (LÖNNERVALL; SUNDELL, 2018; GENNARI, 2018).

Neither this community nor the cultural agents of Marvila recognize an effective invitation from the $\mathrm{HCB}$ to participate in its implementation process (NUNES; POGGEMANN; POMESANO, 2020; LÖNNERVALL; SUNDELL, 2018). This lack of dialogue in the construction of a "common" and sharing it (RANCIÈRE, 2005) can be understood as one of the greatest ambiguities of the project. Considering that a creative community is not only constituted from "technologies and talents", as the HCB proclaims, but also from the "tolerance" to diversities of ideas, ethnic, socioeconomic and cultural (SCALZOTTO, 2020-b; GENNARI, 2018).
This argument is illustrated by the recent project of the complex - "A Praça (The Square)" -, a food market or "mega restaurant market" (GUERREIRO, 2020) that occupies two buildings, with $1700 \mathrm{~m}^{2}$. With an "international" signature of the Broadway Malyan Portugal office, the program involves stalls, public canteens, restaurants, shops, a school and, outside, terraces and vegetable gardens, following a "fashion" of gourmetization in the markets. Guided by the concepts of "sustainability, innovation and social", the "Praça" seeks to offer excellent products of the Portuguese tradition coming from small and medium-sized producers linked to sustainable agriculture, listed from various parts of the country. In addition, to contemplate "integration" with the Beato community, it proposes, in an assistentialist way, a Social Meal Grant for needy families (HCB, 2020). The initiative, therefore, disregards local potential, such as the cultivation of spontaneous vegetable gardens present in the territories of Beato and Marvila (ADAGÓI, 2015), whose agents could be trained for the referred "qualityproduction". On the other hand, with the "Portuguese and ecological" identities, the products offered by the "A Praça" are sure attractions for the consumption of global, entrepreneurial, culturally experienced and wealthy young people (SCALZOT'TO, 2020B), which does not include the locals.

Also with regard to the program, the housing issue deserves special attention. Despite the numerous housing problems and the growing processes of gentrification in Lisbon (NEVADO, 2018), the proposal is, quantitatively, timid. Only one of its buildings will be dedicated to colivings or shared residences, directed only to $\mathrm{HCB}$ guests. This fact, added to Beato's prospect of real estate speculation with the implementation of the HCB, indicate that the parish could be the next target of Lisbon's gentrification (SCALZOTTO, 2020-a, 2020-b; LÖNNERVALL; SUNDELL, 2018; GENNARI, 2018).

${ }^{7}$ The topic was also alerted by a resident of the region to the authorities present at the event I participated in - Zona Ribeirinha de Marvila. Que Futuro? -, which took place at the Clube Oriental de Lisboa, on January 23, 2020. 
This low investment in housing may have economic motivations, because the compartmentalization of the program, demands for ventilation-lighting installations and requirements for easy-to-maintain internal finishes are more onerous, compared to simple adaptations of free plants and rustic finishes assimilated by other programs (GUIDOLIN, 2016). In parallel, largescale housing is promoted in new and profitable private developments, stimulated by legal instruments and marketing strategies that, like the $\mathrm{HBC}$, are supported by the figure of pop-star architects and/or by the image of local heritage. Jardins Braço de Prata Complex (1999-2011), in Marvila, by architect Renzo Piano, illustrates this argument. This project with 500 luxury homes decharacterizes the industrial typologies of the parish and, considering the profile of possible consumers, will create a social ghetto (COSTA, 2020).

The HCB project, therefore, cannot be analyzed in isolation. It is part of a broader, neoliberal urban strategy that uses the city for the circulation of capital and housing as a commodity. Which, despite an "inclusive and integrative" discourse, is indifferent to possible urban and social problems. It is in this context that Browers Beato Brewing Company is inserted.

\section{THE BREWERY}

\section{Rule of the game - beritage and intervention}

The Bread, Biscuits and Grinding factories are understood as essential to the identity of the set in the "Auto de Cedência" and, in the listing of the Municipal Heritage Charter, there are only the Power Plant (1921) and the Convento das Grilas (17th and 18th century). Which, hypothetically, would require the municipality to evaluate and inspect the interventions in these buildings.

Despite individual attributes, the HCB considers that the set - buildings and infrastructures - has historical and urbanistic value, due to its industrial legacy, its socio-cultural value, and its collective social memory. Thus understood, changes and extensions are permitted on them, when adaptations of use and legal requirements are imposed. In these cases, based on heritage charters, the identity and architectural integrity should be guaranteed by the legibility of the new, reconstituted and the old, by the conservation of the structuring elements of pre-existing spaces and by the interpretation and evocation of the old functions, retaining its meanings. Demolitions, total or partial, are also allowed, when the state of degradation or structural precariousness of the buildings does not allow for their recovery and/or rehabilitation, or when they allow for the "value of the property". In addition to the buildings, equipment and manufacturing infrastructure must be preserved, documented and be part of museums' collection.

In all cases - construction, expansion and alteration -, the aim is to respect existing morphological and typological characteristics, maintaining alignments and adopting height restriction measures. Thus, interventions inside buildings and, on the façades, access spans, stairs and elevators are privileged. Changes in volume occur in a subtle way - roof elevations to create new floors and terraces; 1 to 2 floors additions; and deleting some attachments. In the case of new buildings, harmonization with adjacent heights and exploration of visuals is sought.

A diagnosis offered by the HCB would guide interventions. It would contain historical documentation, architectural survey and states of conservation and pathologies, with an indication of notable and dissonant elements and recommendations on what to protect, demolish or replace. The companies installed would be autonomous and responsible for the design and construction, its costs would be deducted from the payment of the space lease, leased over a long term.

\section{The functional and aesthetic proposal}

he brewery occupies the Old Power Plant, with $700 \mathrm{~m}^{2}$, listed in the Municipal Heritage Charter, as mentioned (element 6 - Figure 4). It is a pavilion of 


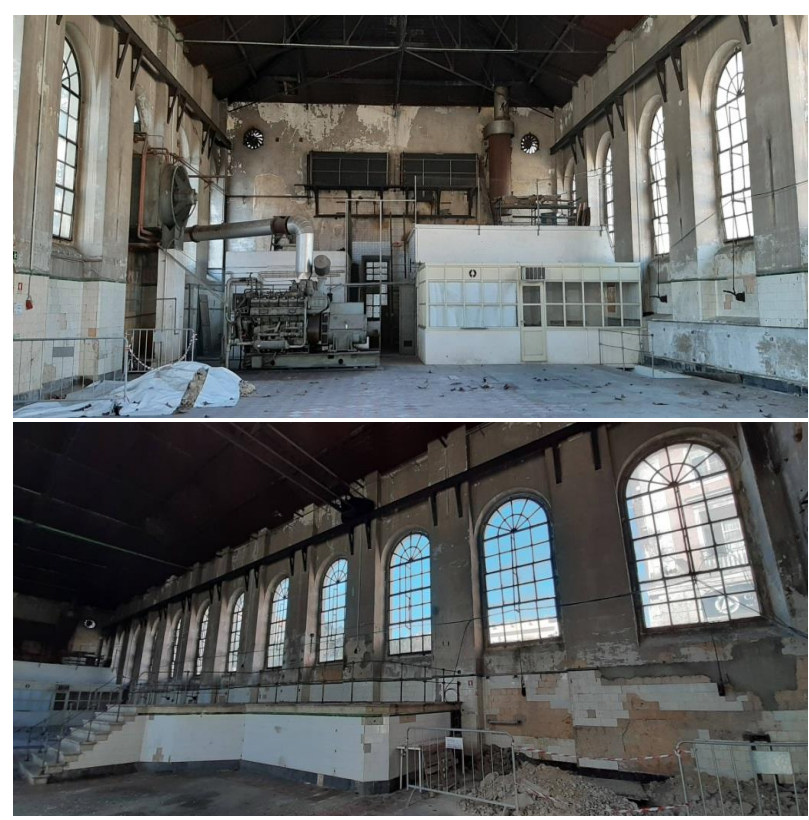

Figure 5: Internal views. Power plant. HCB. Lisbon.

Source: the author.

great spatial quality - a longitudinal nave, with high ceilings, articulated by the rhythm of windows and scissors and by the cadence of light. Platforms and machinery reveal their original functions. The quality of the original colors and textures adds to the patina of time that emerges from its peeling walls and the rust of its equipment (Figure 5).

According to Souto de Moura (MOREIRA, 2018), we sought to maintain the building's original design, exploring details in its interior. "The facades are done in an ancient language. The interior is modern, because it has to be". The project thus follows premises established by the HCB for the preservation of the original volumes, also contemplating the demolition of annexes on the south façade, to reopen the original door, and the opening of a gate on the north façade (Figure 6).

A long longitudinal counter that separates public areas (restaurant/bar, events area and restrooms) and private areas (kitchen, pantry, preparation areas and microbrewery) organizes the spatial arrangement. The two existing platforms are preserved: the longitudinal one supports the microbrewery; and the transversalnorth, the stage for presentations and for film

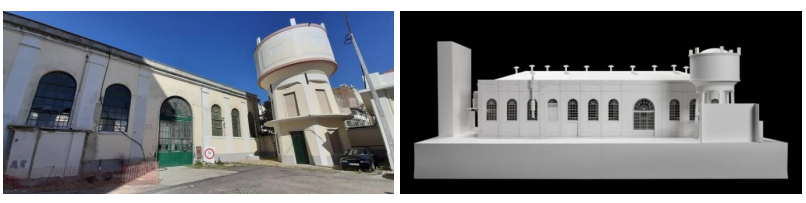

Figure 6: External view and Mockup. Browers Beato Brewing Company. Souto de Moura and Graça Moura. 2017. Lisbon. Source: the author; Moura (n.d).
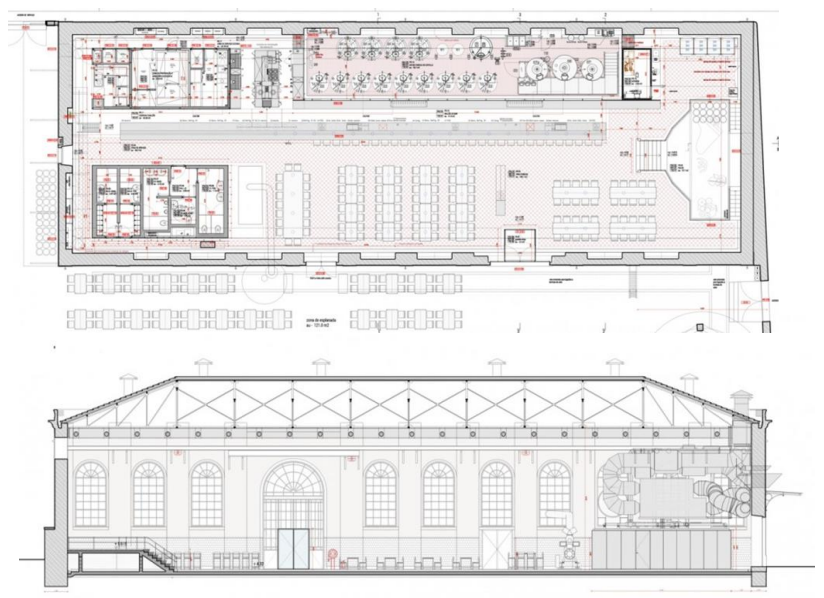

Figure 7: Floor plan and cut. Browers Beato Brewing Company. Souto de Moura and Graça Moura. 2017. Lisbon. Source: Moura (n.d).

projections. The program, articulated in and from the free plan, is flexible and accepts the idea of "place" in contemporaneity, as suggested by Montaner (2012), with a focus on dynamic events and ephemeral flows.

This arrangement demonstrates an unquestionable sensitivity in recognizing and preserving the spatial qualities of the building and the industrial identity, expressed in the platforms and machinery. Thus, it appeals not only to the typological attributes of the space, but also to the elements that are linked to the industrial archetype.

In the finishes, the restoration of paneling, tiles and mosaics on the walls and the use of hydraulic tiles on the floors, with design and colors identical to the existing ones, rescue the original atmosphere of the building, despite that they can be questioned about their readability in the pre- existence. The open joints and acoustic insulation of the ceiling and the laminated double-glazing on the iron windows show equal care with the building's integrity and adequacy to thermal conditioning. 
Aesthetically, the new mechanical installations are apparent, along with the ceiling and façades. The stainless steel of the brewery and the volumes of the kitchen, counter and toilets are formally and constructively opposed to pre-existing conditions. The bareness, the "truth of materials" of modernist pragmatism, gains formal expression (DIEZ; DI PECO, 2013). On the other hand, all interventions can be subtracted in any future interventions, without compromising the original integrity of the building. This guarantees the readability and reversibility suggested by the patrimonial charters (Figure 8).

The proposal is developed without the appeal of successful solutions in the society of the spectacle, such as media and interactive containers that often make the spatiality of pre-existence imperceptible (MONTANER, 2012). Nor does it explore the fad of a "decadent"appearance, withcheap materialsorelements succumbed by time that recall a nostalgic past. As has been the case in Marvila and as the missing elements
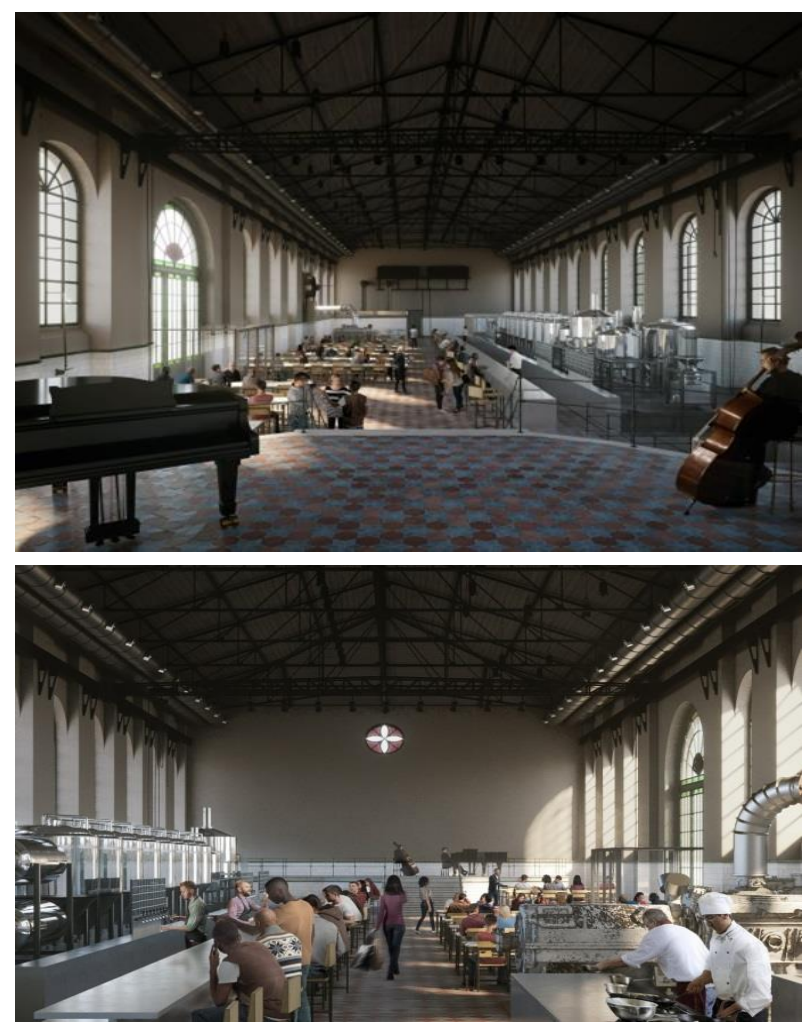

and rust from the Power Plant might suggest (COSTA, 2020; DIEZ; DI PECO, 2013; HUYSSEN, 2006).

In a sense, the proposal is still a symbolic product of modern culture, it aesthetically "sacralizes" the object and, by resorting to noble materials, it intends to guarantee the aspect of the eternally new, well executed (MONTANER, 2012). A possible conceptual counterpoint to this in contemporary times would be the one suggested by Diez and Di Peco (2013), in which the sacralization of the object is abdicated in favor of economic, socially fair and, at times, apparently rustic or sustainable solutions?

\section{Criticism - Between the aesthetic and the ethical}

This "socially just" argument is highlighted and expanded here, because it raises the aesthetic and ethical issues addressed in this study. In the perspective already defended in the introduction, the project should not be restricted to the focus of aesthetic themes within the limits of an envelope, but also encompass reflections and actions on the "inevitable damages" of this gesture in the physical-social context of its insertion. In this sense, rehabilitation projects would assume some ethical perspective of requalification, when supported by the involvement of all affected and a case-by-case reflection, questioning universalizing values (NEVADO, 2018; RANCIÈRE, 2005).

In a report by Melo e Castro (2018), Fernando Medina, from the CML, expresses the desire that the industrial zones of Lisbon take on "new" ideas, such as those in London and New York. Moreover, Souto de Moura states that, to carry out the project, visits were made to micro-breweries in several cities - "I was enchanted with the colors of the beers and I really liked that there could be a line of stores here, linked to this universe and with complementary products".

Figure 8: Perspectives. Browers Beato Brewing Company. Souto de Moura and Graşa Moura. 2017. Lisbon.

Source: Moura (n.d). 
The speeches of the politician and the architect, therefore, reveal the adoption of standard models, imported and, essentially, far from the local reality. They are, however, models compatible with the commercial ambitions of major Portuguese brands and companies. Super Bock, together with other international brands, takes on the role of promoting a brewing "culture". Multifood, which represents the brands Vitaminas, Wok-to-Walk, Pizzaria Zero-Zero and Hamburgers Honorato (MOREIRA, 2018), takes over the food court. As in the "A Praça" project, quality products are offered here, pasteurized, gourmetized, and ready for easy and expensive consumption.

Would this "business" model be suitable for the Beato? From an ethical and social perspective, will not the Brewery weaken the small breweries and local restaurants? Could it not be a promoter of these small businesses or an articulator of training and income generation? Will not it create a consumer niche that will exclude the local community? In addition to the Brewery, the speech of one of the HCB managers answers part of these questions - the process will ensure the survival of a few small local companies, only those "suitable". For example, those with assistanceinEnglish, which, however, is not a problem for the $\mathrm{HBC}$, as they are not "social workers" (SCALZOTTO, 2020-a).

Thus, the solution is given to models and fads, abdicating to generate its own solutions, related to local culture, techniques and material and human resources. As Montaner (2012) observes, cultural imperialism converts solutions into multinational products imposed on different contexts, consolidating "non-places" that, thematized and dedicated to tourism and individualistic consumption, do not create interrelationships.

\section{FINAL CONSIDERATIONS}

The analysis of the projects of the Brewery and the HCB provides opportunities to raise questions related to the ethical-aesthetic role of the professional work of the architect and urban planner. Souto de Moura's valuable lessons in the Brewery project are indisputable, as are (potentially) relevant the intentions of the $\mathrm{HCB}$ project to stimulate the eastern region of Lisbon. However, in addition to the lessons and intentions, the contemporary condition seems to demand reflection on its social and political consequences.

In this sense, the two proposals have ambiguities. The brewery project does not eliminate the "place" condition of the old power plant, highlighting its aesthetic qualities through unquestionable care with the intervention, but also supports the condition of "non-place", ethically uncommitted to the social context in which is inserted. The same happens in relation to the HCB project. Its urban rehabilitation discourse encompasses the interest in attracting global investments, disregarding local actors, which foresees the aggravation of social and urban problems in Beato and, consequently, in Lisbon. The proposal for the brewery sacralizes its object, the "customer" and the figure of the star-architect. HBC's proposal sacralizes investors. Both intertwined by the architecture of the spectacle Therefore, at different scales, one of the many contemporary territories is installed, in which "places and non-places intertwine, complement each other, interpenetrate and coexist"'(MONTANER, 2012,p.49).

The diagnosis of this ambiguity, beyond a simple denunciation, reveals to be an opportunity to broaden reflections on the "fair" project and its demands for an ethical positioning of the architect and/or the awareness and expansion of the ethical consequences of his/her actions. It is expected, therefore, to build more solid project bases that allow (de)construct established discourses and practices, as well as universal and homogenizing solutions that, for a long time, have focused on heritage, planning and design. 


\section{REFERENCES}

ADAGÓI, Maria Inês Martins. Os Alimentos que vêm dos Vazios. As Hortas Urbanas Dispersas e Serviços de Ecossistema. Caso de Estudo dos Bairros da Freguesia de Marvila, Lisboa. 2015. 114f. (Mestrado em Arquitetura Paisagista). Instituto Superior de Agronomia da Universidade de Lisboa, 2015.

BRANCO, Miguel; RODRIGUES, Luís Filipe. Marvila: o Lisbon Beer District. TimeOut, Lisboa, 05 fev. 2019. Disponível em: https://www.timeout.pt/ lisboa/pt/coisas-para-fazer/marvila-e-o-novo-lisbonbeer-district. Acesso em: 10 fev. 2021.

COSTA, Ana Elísia da. Decadência com Elegância: estética e consumo da habitação em tempos de crise. Cadernos Pós. Cadernos de Pós-Graduação em Arquitetura e Urbanismo da Universidade Mackenzie, São Paulo, v. 2, n.2, p. 24-41, 2020.

DIEZ, Fernando; DI PECO; Martín. A forma do Informalismo. Summa +, Buenos Aires, n. 130, p. 90 97, ago. 2013.

GENNARI, Carlotta. Regeneração Urbana, Cidade Criativa e Gentrificação: Estudo do caso de Marvila em Lisboa. Sociabilidades Urbanas - Revista de Antropologia e Sociologia, v2, n6, p. 113-123, nov. 2018.

GUERREIRO, Adriano. A Praça: o novo mega mercado de restaurantes que vai abrir no Beato. NIT, Lisboa, 12 out. 2020. Disponível em: https://www. nit.pt/comida/restaurantes/a-praca-o-novo-megamercado-de-restaurantes-que-vai-abrir-no-beato. Acesso em: 10 fev. 2021.

GUIDOLIN, Francesca. Improving Strategies for Functional Upgrade for An "Integrated Rehabilitation". IN: 3rd International Academic Conference On Places And Technologies, 2016, Belgrado. Anais... Belgrado: University of Belgrade, 2016, p. 687-750. Disponível em:http://www.placesandtechnologies.eu/wp-
content/uploads/2016/04/Book-of-Proceedings-_Digital-_-687-750.pdf. Acesso em: 10 out. 2019.

HCB - HUB CRIATIVO DO BEATO. Hub Criativo Beato. Memória Descritiva e Justificativa do Projeto Global para o Hub Criativo do Beato. Lisboa, jan. 2018. Disponível em: https://docplayer.com. br/175515436-Projeto-global-para-o-hub-criativo-dobeato.html

HCB - HUB CRIATIVO DO BEATO. Praça é o novo projeto que vai integrar o Hub Criativo do Beato. Lisboa, 09 out. 2020. https://hubcriativobeato.com/ noticia/praca-e-o-novo-projeto-que-vai-integrar-ohub-criativo-do-beato/. Acesso em: 10 dez. 2020.

HUYSSEN, Andreas. Nostalgia for Ruins. Grey Room, MIT Press Journals, n. 23, p. 6-21, 2006. DOI: https://doi.org/10.1162/grey.2006.1.23.6

JFB - JUNTA DA FREGUESIA DO BEATO. A nossa freguesia. História. Lisboa, n.d. Disponível em: https://jf-beato.pt/seculo-a-seculo/. Acesso em: 15 jan. 2019.

KENDZIOR, Sarah. Gentrificação: os perigos da economia urbana hipster. ArchDaily Brasil, 30 Nov 2014. Disponível em: https://www.archdaily.com. br/br/758003/gentrificacao-os-perigos-da-economiaurbana-hipster . Acesso em: 24 set. 2018

LARA, Larissa Michelle. O sentido ético-estético na cultura popular. 2004. 226p. Tese (Doutorado em Educação). Faculdade de Educação da Universidade Estadual de Campinas, Campinas, 2004.

LIPOVETSKI, Gilles; SERROY, Jean. Estetização do Mundo. Viver na era do capitalismo Artista. São Paulo: Companhia das Letras, 2015. 472p.

LÖNNERVALL, Solveig; SUNDELL, Michaela. Hub Criativo do Beato: For whom by whom? A narrative study of global entrepreneurial and creative urban practices in the eastern riverside of Lisbon. 
2004. 50f. Dissertação (Mestrado em Planejamento e Design Urbano Sustentável). Escola de Arquitetura do Instituto Real de Tecnologia de Estocolmo, Estocolmo, 2018.

MELO E CASTRO, Rosário. Tudo o que vai acontecer no Hub Criativo do Beato, a nova microcervejeira de Lisboa. SAPO. Lisboa, 29 mai. 2018. Disponível em: https://visao.sapo.pt/visaose7e/sair/2018-05-29tudo-o-que-vai-acontecer-no-hub-criativo-do-beatoa-nova-microcervejeira-de-lisboa/. Acesso em: 15 jan. 2020.

MONTANER. Josep Maria. A Modernidade Superada: Ensaios sobre a arquitetura contemporânea. 2. ed. São Paulo: GG, 2012. 183p.

MONTANER. Josep Maria; MUXÍ, Zaida. Arquitetura e Política: Ensaios para mundos alternativos. São Paulo: GG, 2014.

MOREIRA, Cristiana Faria. Vai ser feita cerveja na antiga central eléctrica da Manutenção Militar de Lisboa. Público, Lisboa, 29 mai. 2018. Disponível em: https://www.publico.pt/2018/05/29/local/noticia/ vai-ser-feita-cerveja-na-antiga-central-electrica-damanutencao-militar-de-lisboa-1832594. Acesso em: 15 jan. 2020.

MOURA, Nuno Graça. Transformação da Antiga Central Eléctrica da Manutenção Militar em microcervejeira e restaurante Browers Beato. Porto, n.d. Disponível em: http://nunogracamoura.com/ pt/099-2. Acesso em: 15 jan. 2020.

NEVADO, Ana Catarina Serra. Da expansão à recentralização - do território ao património. A regeneração urbana da zona ribeirinha oriental de Lisboa (1964-1994). Lisboa, 2018, 289 p. Tese (Doutorado em Arquitetura dos Territórios Metropolitanos Contemporâneos). Departamento de Arquitetura e Urbanismo do ISCTE - IUL, Lisboa, 2018.
NEVADO, Ana Catarina Serra. Ressignificar lugares: regeneração urbana como processo de memória coletiva. O caso do Hub Criativo do Beato. In: PNUM2018: A Produção do Território: Formas, Processos, Desígnios, 2018, Porto. Atas do Congresso..., Porto: Faculdade de Arquitectura da Universidade do Porto, 2020, p. 1893-1902.

NEVADO, Ana; ANDRÉ, Paula. Visões práticas e colaborativas em casos de regeneração urbana em Lisboa. In: ANDRÉ, Paula; RODRIGUES, Paulo Simões; ALVES, Margarida Brito (Ed.). Laboratório Colaborativo: dinâmicas urbanas, património, artes. Lisboa: DINÂMIA'CET-IUL, 2018, p. 9-31.

NUNES, Diogo Ferreira. Super Bock Group investe três milhões em microcervejeira no Beato. Dinheiro Vivo, Lisboa, 29 mai. 2018. Disponível em: https:// www.dinheirovivo.pt/empresas/galeria/super-bockgroup-investe-tres-milhoes-em-microcervejeira-nobeato/. Acesso em: 15 jan. 2020.

OCHOA. Ana Rita. Dinâmicas de Crescimento em Metrópoles Portuárias. Tensões a Oriente da Cidade de Lisboa. On the Whaterfront, n. 7, p. 30-41, set. 2005 Disponível em: https://raco.cat/index.php/ Waterfront/article/view/217110 . Acesso em: 15 fev. 2020.

RANCIÈRE, Jacques. A Partilha do Sensível: estética e política. São Paulo: EXO Experimental, 2005.

REIS E SILVA, Margarida. Para onde a indústria os levou: crescimento urbano de Marvila e Beato a partir de 1835. Cadernos do Arquivo Municipal, Lisboa, $2^{\mathrm{a}}$ série, n.12, p. 117-140, jul.-dez. 2019

SCALZOTTO, Joel Göransson. It's the Smart City, Stupid! A critical study of Smart narratives, Attraction Hysteria \& the production of Smart Space in the European Green Capital 2020. Estocolmo, 2020, 75f. Dissertação (Mestrado em Globalização, Meio Ambiente e Mudança Social). Instituto de Geografia Humana da Universidade de Estocolmo, 2020a. 
SCALZOTTOO, Joel Göransson. Smart-Up Urbanism: Critical Reflections on a Hub, Urban Regeneration \& Smart Cultural Imaginaries in Lisbon. Position Paper. Lisboa: Project ROCK Instituto de Ciências Sociais da Universidade de Lisboa, 2020b. Disponível em: http://hdl.handle.net/10451/44489. Acesso em: 03 mai. 2021.

NUNES, Mafalda Corrêa; POGGEMANN, Tim; POMESANO, Laura. Encontro com Agentes Culturais de Marvila e do Beato. Reseach Report. Lisboa: Project ROCK. Instituto de Ciências Sociais da Universidade de Lisboa, 2020. Disponível em: https:/ / lisboa.rockproject.eu/wp-content/uploads/2020/08/ Relat $\%$ C3\%B3rio-World-Caf\%C3\%A9.pdf . Acesso em: 03 mai. 2021.

SOUTO MOURA, Eduardo. Eduardo Souto Moura e Nuno Graça Moura transformam antiga Central Eléctrica. Espaço de Arquitetura, Guimarães, 04 Jun. 2020. Disponível em: https://espacodearquitetura. $\mathrm{com} /$ noticias/eduardo-souto-moura-e-nuno-gracamoura-transformam-antiga-central-electrica/. Acesso em: 03 jul. 2020. 